\title{
Evaluation of the Service Process to Students in the Payment Area Applying Simulation
}

\author{
Gonzalez Torres Arturo \\ Instituto Tecnológico de Tláhuac II \\ Delegación Tláhuac, Ciudad de \\ México, México
}

\author{
Romero Arellano Silvia \\ Universidad Insurgentes \\ Iztapalapa, Ciudad de México, \\ México
}

\author{
Chávez Hernández Noemí \\ Universidad Insurgentes \\ Iztapalapa, Ciudad de México, \\ México
}

\begin{abstract}
The present research work has the purpose of performing an evaluation of the service process to students in the payment area, for which a study was carried out employing a reliability of $95 \%$ with the simulation technique. A descriptive - analytical methodology was developed with a population sample of 68 students. The results obtained helped to measure in the first instance the service process, resulting in a $66.66 \%$ integral result; Also applied a study of activities that do not add value, the operating times were readjusted. With these recommendations it was possible to improve productivity to $100 \%$ in the process of service to students in the payment area.
\end{abstract}

Keywords-- payment area, simulation, productivity

\section{INTRODUCTION}

The simulation is developed with the theory of statistical sampling and analysis of complex physical probabilistic systems. The common aspect of both is the use of random numbers and samples to approximate solutions (Ferreiro, Azcárate y Mallor, 2011).

FIB ( $\mathrm{s} / \mathrm{f}$ ) mentions that the origins of the simulation go back to World War II when the mathematicians Neumann and Ulam, had the challenge of solving a complex problem related to the behavior of the neutrons.Experiments based on trial and error were very expensive and the problem was too complicated to be addressed by analytical techniques. The approach they chose is based on the use of random numbers and probability distributions. The method developed was called "Monte Carlo Method" by the generation of random numbers and the game of roulette.

Muñoz (2009) cites that the simulation is a technique that through mathematical and supposed logical conditions, allows to represent a real system. In general, the simulation process is performed by computer software.

According to Kelton, Sadowski\&Sadowski (2008) mention that the simulation is an ample collection of methods and applications that allow to imitate the behavior of a real system. The simulation, can be an extremely general term, that applies in many fields, industries and other applications.

Banks, Carson and Nelson (1996) define a simulation model as a descriptive model of a process or system, which usually includes parameters to represent different configurations of the system or process. In addition, he says that the simulation can be used to experiment, evaluate and compare many alternative scenarios. The results it delivers are performance prediction and identification of system problems.

Vargas (2015) mentions that the simulation refers to the set of methods and applications that seek to imitate the behavior of real systems, usually on a computer with appropriate software. The simulation of a real fact or a process by means of another simpler 
process that analyzes its characteristics is a practical tool of engineering. One of the best known is the finite element method, which helps with mathematics and physics to explain processes (Puche, 2005).

\section{HISTORY OF THE UNIVERSITY INSURGENTES}

The Insurgentes University celebrates 20 years of existence in the educational field of Mexico City; nevertheless, its origins date back to 1976 when the Executive College of Mexico was constituted as a response to the demand for commercial technical education, but since then its objective was to become a solid institution of higher education (Universidad Insurgentes, 2017).

Congruent with its Philosophy and Mission, and immersed in a dynamic of constant improvement, we have assumed throughout our trajectory, innumerable challenges that have been translated into work and dedication and, at the same time, in achievements and satisfaction; One of them is the experience of applying a system of self-recognition (self-study) that involved the entire university community; This process was in itself an enriching lesson and even more, the result: a large sum that is poured into institutional improvement (Universidad Insurgentes, 2017).

\section{HISTORY OF THE SPECIALIZED SOFTWARE ProModel®}

ProModel Corporation (s / f) mentions that ProModel ${ }^{\circledR}$ is an animated simulator for personal computers. It allows to simulate any type of systems of manufacture, logistics, handling of materials, etc. You can simulate transport belts, traveling cranes, assembly, cutting, workshops, logistics, etc. With the software you can simulate: Just in Time, Theory of Constraints, Systems of Push, Pull, Logistics, etc. Virtually any system can be modeled. Likewise, ProModel Corporation ( $/ \mathrm{f}$ ) mentions that once the model is made, it can be optimized to find the optimal values of the key parameters of the model. Some examples include determining the best combination of factors to maximize production by minimizing cost, minimizing the number of trucks the service, etc.
Evaluate the process of service to students in the cash area applying simulation

\section{SPECIFIC OBJECTIVES}

$>$ Know the process of service to the students in the payment process.

$>$ Understand the hierarchy of the service process for students in the payment process.

$>$ Simulate the process of service to students in the payment processusing specialized software

$>$ Analyze the productivity of the service process to students in the payment process.

$>$ Evaluate the results obtained from the analysis of the productivity of the service process to students in the payment processto propose improvements to it.

\section{METHODOLOGY}

The organization process to carry out this investigation was carried out as follows, we support ourselves to see the difference in time of the observations of the payment process.

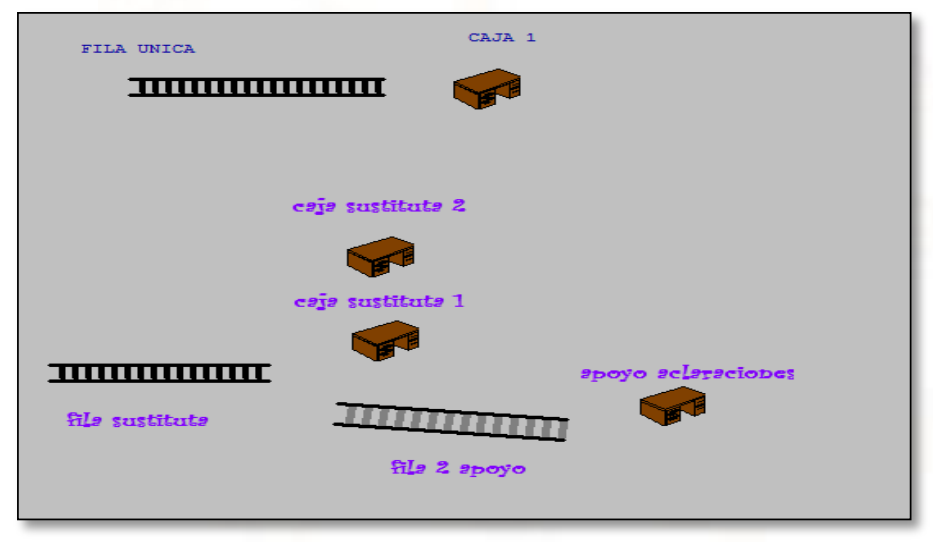

\section{Figure 1: Example of the payment process}

The process is monitored; the entrance time is 9 a.m. At 3 p.m. Also, it is known that they have 60 minutes to eat, they have 40 minutes dead on average, because the machines do not start the first, it was discovered that they do not give them maintenance in a row. On the other hand it was found that on average the workers lose 20 minutes to find the pending files and activities to perform for the following day. With the monitored, an effective time of 4 hours is given, this time will serve to simulate the process.

\section{GENERAL OBJECTIVE}


As a next step, each activity is monitored to find the average time it takes each activity. The formula proposed by Salas (s / f) was used to know how many time samples should be made.

$$
n=\frac{Z^{2} * p[1-p]}{E^{2}}
$$

Where:

$\mathrm{n}=$ is the number of times taken to develop.

$\mathrm{Z}=$ is the confidence interval to be used. For this project $95 \%$ reliability was used.

$\mathrm{p}=$ is the probability of success. For this project was used a 0.5 of success.

$\mathrm{E}=$ is the percentage of error allowed. For this project $5 \%$ was used.

$$
n=\frac{(1.645)^{2} * 0.5[1-0.5]}{(0.10)^{2}}=\frac{0.6765}{0.01}=67.65=68
$$

For the present project, using 95\% reliability, 5\% error, a success probability of $0.5,385$ time takings were made for each activity. Table 1 shows an example of the average time for each activity of the payment process.

\section{RESULTS OF THE OBSERVATION}

The result of the observations made showed that the effective working time is 4 hours. Likewise, there is loss of time due to lack of maintenance and clutter in the jobs. Continuing with the analysis, the processing times using $95 \%$ and a maximum allowed error of $5 \%$ are shown in the following:

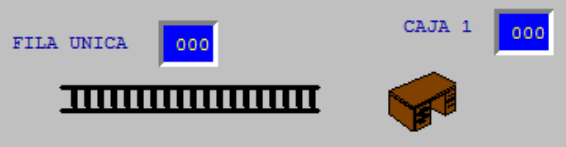

c9je sustitute 2

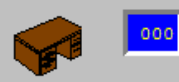

c9je sustitute 1

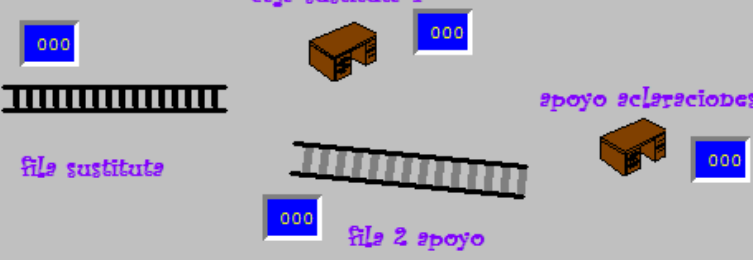

Figure 2: Example of the payment process

In the previous figure, the process is already complete, and then the simulation stage was used. ProModel@ specialized software was used, using the formula proposed by Diaz (1995), who proposes a formula to know the number of runs to simulate a process, in this case, the payment process.

The formula used was as follows:

$T=\frac{t_{\alpha}^{2} p_{h}(1-P h)}{A^{2}}$

Where:

$\mathrm{T}=$ is the number of replications,

$\mathrm{Ph}=$ is the default imprecision level $\mathrm{A}$

$1-=$ is the confidence level

For this investigation it was calculated with a confidence interval of $99 \%$, using a right tail of probability of 0.05 and a level of imprecision of 0.05 . The theoretical probability of the interval according to the author is in a range $(0.045-0.055)$. The formula will be as follows:

$$
T=\frac{t_{\frac{\alpha}{2}}^{2} p_{h}(1-P h)}{A^{2}}=\frac{(2.57)^{2} * 0.05 *(1-0.05)}{(0.05)^{2}}=\frac{0.3136}{0.0025}=125.44 \approx 126
$$


The result shows that for reliability of $99 \%$ and inaccuracy of 0.05 , the chain map was simulated 126 times in its current state.

\section{ANALYSIS OF RESULTS}

ProModel ${ }^{\circledR}$ specialized software helps to evaluate the charging process, Table 1 represents an example of the results.

Table 1: process example

\begin{tabular}{|l|c|}
\hline Variable & Total \\
\hline Students Served & 32 \\
\hline Students in queue & 16 \\
\hline Total & 48 \\
\hline & \\
\hline Productivity & 66.66 \\
\hline
\end{tabular}

It can be observed that the results obtained from the observations in the specialized software have a $66.66 \%$ productivity; this analysis resulted from observations of approximately four hours, given the minutes lost due to lack of maintenance and the loss of time in searching for pending and next day information. The ProModel® software showed a total of 24 correctly attended students and a total of 16 students who stand in the queue waiting for service.

Also, the software shows the percentage of work in each work area. It can be observed that an equal result is not shown in the processes, which means that some activities work more than others. It can be deduced that there are areas of improvement in the process of attention to students. Figure 3 shows an example of the productivity of each work area.

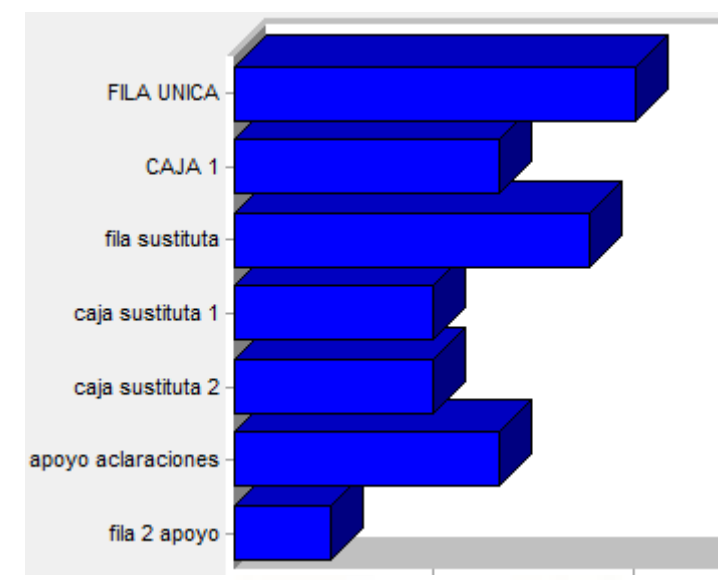

Figure 3: Process example

\section{CONCLUSIONS}

With the study presented, it was possible to evaluate the process of service to students in the payment area applying simulation. Also, the process of service to the students in the box area was known. The hierarchy of the service process was understood to the students in the box area. The service process was simulated to the students in the box area using specialized software. We analyzed the productivity of the service process to the pupils in the box area. Finally, it was possible to evaluate the results obtained from the analysis of the productivity of the service process to students in the cash area to propose improvements to it.

\section{PROPOSAL FOR INTERVENTION}

Once the productivity of the students' attention process is known, the following improvements are proposed:

Have a maintenance plan, with this will reduce on average the 40 minutes that are presented in the machines of the workers.

> Have an orderly, clean and classified place, this will reduce on average the 20 minutes that the workers take to find the pending jobs and the next day's work.

$>$ Develop an analysis of activities in each area of work, in order to eliminate activities that do not add value in each process. This proposal will help reduce the times of each activity. 
With the proposals mentioned, the process was simulated again and the results obtained were as follows:

Table 2: Process example

\begin{tabular}{|l|c|}
\hline Variable & Total \\
\hline Students Served & 48 \\
\hline Students in queue & 0 \\
\hline Total & 48 \\
\hline & \\
\hline Productivity & 100 \\
\hline
\end{tabular}

It can be observed that the results obtained from the observations in the specialized software have a $100 \%$ of productivity; This analysis results from observations of approximately four hours, given the minutes that are lost due to lack of maintenance and the loss of time in searching the pending and the following day's information. ProModel® software showed a total of 48 correctly attended students and a total of 0 students left in the queue waiting for service.

\section{ACKNOWLEDGMENT}

M.I.I. Arturo González Torres por su asesoramiento, tutoría y dirección del proyecto

\section{REFERENCES}

1) Banks, J., Carson, J. S., Nelson, B.L. (1996). Event System Simulation. Second Edition. Prentice Hall, New Jersey.

2) Díaz Emparanza, I. (1995). Selección del número de replicaciones en un estudio de simulación. Departamento de Econometría y Estadística. Universidad del País Vasco EuskalHerrikoUnibertsitatea.

3) Facultad de Informática de Barcelona. (s/f). Simulación. Facultad de Informática de Barcelona

4) Ferreiro Villaluenga, M., Azcárate Camio, C. y Mallor Giménez, F. (2011). Simulación del proceso productivo de INASA FOIL, S. A. Escuela Técnica Superior de Ingenieros Industriales y de Telecomunicación.

5) González Hernández, I. J. (2015). Simulación. Área Académica Licenciatura en Ingeniería Industrial. Escuela Superior de Ciudad Sahagún. Universidad Autónoma del Estado de Hidalgo.

6) Kelton, David.,Sadowski, Randall y Sturrock, David. Simulación Con Software Arena. 4 th. ed. México, Mc Graw Hill. 2008. pp 1-194.

7) Muñoz Soto, D. A. (2009). Aplicación de simulación discreta para un sistema de logística militar basado en casos históricos de la segunda guerra mundial. Depto. Ingeniería Industrial. Facultad de Ingeniería. Universidad del BioBio.

8) ProModel Corporation. (s/f). ProModel. ProModelCorporation.

9) Puche Forte, J. F. (2005). Guía Práctica para la Simulación de Procesos Industriales. CETEM.

10) Salas Bacalla, J. (s/f). Muestreo de Trabajo. Biblioteca Central Pedro Zulen. Universidad Nacional Mayor de San Marcos.

11) Universidad insurgentes (2017) se observó el día 15 de marzo 2017 http://www.universidadinsurgentes.edu.mx/quiene s-somos/

12) Vargas Avilés, J. R. (2015). Introducción a la Modelación y Simulación de Sistemas. Curso de Simulación de Sistemas. 